\title{
Activity and localization of lipoxygenase in the ovule of Larix kaempferi (Lamb.) Carr. during megasporogenesis
}

\author{
Aleksandra Seta-Koselska • Ewa Szczuka • \\ Mariusz Spaczyński • Ewa Skorzynska-Polit
}

Received: 19 May 2014/ Accepted: 1 October 2014/Published online: 12 October 2014

(C) The Author(s) 2014. This article is published with open access at Springerlink.com

\begin{abstract}
The anatomical structure of the ovule of Larix kaempferi is typical for gymnosperms. During megasporogenesis, three megaspores arranged in one line are formed after incomplete meiotic division. Lipoxygenase occurrence in the Japanese larch ovules was shown by the Western-blotting method and confirmed using native PAGE. The localization of LOX in the young ovule of $L$. kaempferi during megasporogenesis was analysed by the immunogold labelling technique. The activity of the enzyme was measured spectrophotometrically at $234 \mathrm{~nm}$ using linoleic acid as a substrate. The location of LOX was rather random; however, clusters of immunogold particles were often observed in the vacuoles of integument cells. It was found in the cytoplasm, cell walls, vacuoles, starch grains, and nuclei. LOX activity in developing ovules of the Japanese larch was not correlated with the number of antibody-labelled molecules of the enzyme, which may indicate its non-enzymatic function. Two optima for LOX activity, at $\mathrm{pH} 8.0$ and $\mathrm{pH} 7.0$, were found in L. kaempferi developing ovules. The enzyme with a maximum activity at $\mathrm{pH} 8.0$ appeared in ovules with a megaspore mother cell as well as with a triad of megaspores; the second maximum activity (at $\mathrm{pH}$ 7.0) was detected only at the stage with the triad of megaspores in the nucellus.
\end{abstract}

A. Seta-Koselska ( $₫)$ · M. Spaczyński · E. Skorzynska-Polit Department of Plant Physiology and Biotechnology, Institute of Biotechnology, The John Paul II Catholic University of Lublin, Konstantynów 1i, 20-708 Lublin, Poland

e-mail: bionix @kul.lublin.pl

\section{E. Szczuka}

Department of Plant Anatomy and Cytology, Institute of Biology, UMCS University, Akademicka 19, 20-033 Lublin, Poland
Keywords Lipoxygenase - Megasporogenesis - Japanese larch · Larix kaempferi

$\begin{array}{ll}\text { Abbreviations } \\ \text { LOX } & \text { Lipoxygenase } \\ \text { PUFAs } & \text { Polyunsaturated fatty acids } \\ \text { JA } & \text { Jasmonic acid } \\ \text { PMSF } & \text { Phenylmethanesulfonyl fluoride } \\ \text { PVDF } & \text { Polyvinylidene difluoride } \\ \text { PVP } & \text { Polyvinylpyrrolidone }\end{array}$

\section{Introduction}

The commonly occurring lipoxygenases (LOXs; EC 1.13.11.12) constitute one of the largest families of enzymes. The presence of LOXs has been reported from numerous animals (Schewe et al. 1986) and angiosperms (Siedow 1991). They have also been detected in the cells of lower eukaryotes such as Saccharomyces cerevisiae (Schechter and Grossman 1983), algae (Zimmerman and Vick 1973), and fungi (Hamberg 1986) as well as in some prokaryotic organisms, for example cyanobacteria (Beneytout et al. 1989). Moreover, LOX activity has been described in mosses (Stumpe et al. 2006). LOXs have been found in all parts of the studied plants. Their presence has been demonstrated in seeds (Shibata et al. 1987; Schmitt and van Mechelen 1997), pods (Dubbs and Grimes 2000), seedlings (Melan et al. 1993; Skórzyńska-Polit and Krupa 2003), roots (Kolomiets et al. 2001; Melan et al. 1993), cotyledons (Feussner and Kindl 1994), leaves (Grayburn et al. 1991; Stephenson et al. 1998), fruits (Suurmeijer et al. 1998; Smith et al. 1997), flowers (Fukuchi-Mizutani et al. 
2000), inflorescences (Melan et al. 1993), potato tubers (Kolomiets et al. 2001), and anthers (Szczuka et al. 2006). Although LOX is present in a number of plants, its localization in the cells of conifers is still not determined.

LOXs catalyse dioxygenation of long chain of fatty acids, which contain a cis, cis-1,4-pentadiene structure, to hydroperoxy fatty acids (Brash 1999). LOX strongly prefers free fatty acids such as arachidic, linoleic, and $\alpha$-linolenic acids as substrates, but it was also found to have activity with polyunsaturated fatty acids (PUFAs) esterified to phospholipids, neutral lipids such as triglycerides (Feussner and Wasternack 2002) and monogalactolipids (Nakashima et al. 2011). Products of LOX reaction can be subsequently converted to diverse compounds through the action of enzymes involved in so-called LOX pathway. In plants, products of LOX activity have several various functions, e.g. signalling in the defence responses, regulation of the growth and development of plants, and antimicrobial activity (Porta and Rocha-Sosa 2002). In addition, LOXs have been associated with mobilization of storage lipids during germination (Feussner et al. 2001) and used as storage protein during vegetative growth (Fischer et al. 1999). LOX activity also changes in stress conditions e.g. it increases under the influence of heavy metals (Skórzyńska-Polit et al. 2006), in response to drought (Sofo et al. 2004), pathogen attack and/or operation of effectors (Gomi et al. 2002), or injury (Kim et al. 2003).

LOXs are fundamental at early steps in biosynthesis of jasmonic acid (JA). Jasmonates are phytohormones with multiple functions, including plant defence, development, and reproduction. Jasmonates can control cell division and the growth direction, supporting adequate formation of tissues and organs (Koda 1997), regulate the biosynthesis of several secondary metabolites, including terpenoids, phenylpropanoids, and antioxidants, and stimulate expression of genes involved in the biosynthesis of phytoalexins (Avanci et al. 2010). Besides their participation in the crucial physiological processes of development and defence, jasmonates also perform a significant role related to plant reproduction. They are involved in maturation and/or germination of pollen grains, stamen elongation, and correct timing of pollen release (Gfeller et al. 2010). Experiments with tomato plants have indicated that jasmonates mediate a female-sterile phenotype in this species ( $\mathrm{Li}$ et al. 2001). At $15{ }^{\circ} \mathrm{C}$, a large amount of JA in leaves probably blocked flower bud formation in Pharbitis nil (Nam and Yoshihara 2012). Thus, lipoxygenases involved in jasmonate biosynthesis may influence formation of the male and/or female sexual structures of angiosperms. However, little is known about the participation of lipoxygenase in the development of the generative organs of gymnosperms. Therefore, we chose the Japanese larch, a needle-leaf conifer, as the subject of our research.

Larix species are highly valued for the production of strong, durable, and naturally decay-resistant wood used in construction and furniture industry. In addition, larch forests add a great deal to the decorative values of the landscape and they harbour a variety of wild life. One of the obstacles for the cultivation of Larix species is poor seed production. Production of large quantity of empty seeds has been reported for several species such as Larix decidua, $L$. kaempferi and L. occidentalis (Hall and Brown 1977; Kosiński 1987; Owens et al. 1994; Slobodník and Guttenberger 2005). The main biological constraints for seed production in Larix species are abnormal development of the female gamethopyte, degeneration of the ovule or early embryo, premature abortion of female strobili, insufficient female flowering, and perturbation in the pollination mechanism (Philipson 1996; Slobodník and Guttenberger 2000, 2005; Slobodník 2002). Isolation and preparation of the generative organs of gymnosperms is quite difficult because of occurrence of resins and some polyphenolic compounds. This may be a reason why researchers are less interested in the reproduction of gymnosperms.

The study focused on the megasporogenesis in the Japanese larch; additionally, the location and activity of lipoxygenase in the ovule of L. kaempferi were examined.

\section{Materials and methods}

\section{Plant material}

The seed-cone buds of Larix kaempferi at various stages of ovule development were collected in March and April 2006-2008 and 2013 from the Botanical Garden of UMCS in Lublin (Poland).

\section{Immunolocalization}

For immunogold-labelling modified method described by Szczuka et al. (2006) was used. Seed scales with ovules were isolated and fixed in $3 \%$ formaldehyde (freshly prepared from paraformaldehyde) with $2 \%$ glutaraldehyde dissolved in $0.1 \mathrm{M}$ phosphate buffer ( $\mathrm{pH} 7.3$ ), for $24 \mathrm{~h}$ at $4{ }^{\circ} \mathrm{C}$. The plant material was rinsed several times in $\mathrm{PBS}$ and $0.5 \mathrm{M} \mathrm{NH}_{4} \mathrm{Cl}$ in PBS, dehydrated in ethanol and acetone series, embedded in LR White resign (Sigma, USA), and polymerized at $60{ }^{\circ} \mathrm{C}$ overnight. Thin sections (70-75 $\mathrm{nm}$ thickness) were collected on formvar coated nickel grids, treated with aqueous $0.56 \mathrm{M}$ sodium periodate for $30 \mathrm{~min}$, washed in deionized water, and next treated with $10 \mathrm{M} \mathrm{HCl}$ for 10 min followed by a 5-min water wash. The samples were incubated in $1 \%$ BSA in $0.1 \mathrm{M}$ PBS (pH 7.3) for $45 \mathrm{~min}$ at room temperature and then with PBS-BSA containing rabbit anti-LOX polyclonal serum (Agrisera, Sweden) diluted $1 / 800$ for $1 \mathrm{~h}$. After triplicate washing with PBS-BSA (each wash for $10 \mathrm{~min}$ ), the sections were incubated with goat anti-rabbit immunoglobulins conjugated 
with $10 \mathrm{~nm}$ gold particles (GAR-gold, Sigma, USA) diluted 1/50 in PBS-BSA for $40 \mathrm{~min}$ at room temperature. The samples were washed twice in PBS for $15 \mathrm{~min}$ and next in deionized water. The control samples were incubated with GAR-gold, omitting anti-LOX antiserum. In order to visualize intracellular structures in the biological material, the sections were stained with $2 \%$ uranyl acetate for $5 \mathrm{~min}$ and Reynold's reagent for $1 \mathrm{~min}$. All samples were examined and photographed with a Zeiss LEO 912 AB (Carl Zeiss, Germany) electron microscope.

The intensity of the immunogold reaction was determined by counting gold particles on the surface of crosssections of entire cells or fragments of cells. The measurement of the analysed surface was carried out using a standard function of the program (AnalySiS 3.0) supporting a microscope camera. Counting of gold particles was conducted in a video mode of the microscope camera at a magnification $20,000 \times$. The auto scan of a specified area was used in order to eliminate any errors associated with re-counting of immunogold particles.

\section{Determination of LOX activity}

The activity of LOX was measured spectrophotometrically at $234 \mathrm{~nm}$ as described earlier (Skórzyńska-Polit and Krupa 2003). The reaction mixture contained $0.2 \mathrm{M}$ boric acid buffer ( $\mathrm{pH} 6-10)$ or $0.2 \mathrm{M}$ citratic buffer ( $\mathrm{pH} 4-5$ ), $25 \mu \mathrm{l}$ of plant extract and linoleic acid as a substrate in $3 \mathrm{ml}$ of the final volume. The reaction was carried out at $30{ }^{\circ} \mathrm{C}$ for $4 \mathrm{~min}$. The LOX activity was expressed as an absorbance increase per $\mathrm{mg}$ of protein per minute. The protein concentration was measured according to Bradford (1976) using BSA as a standard.

\section{Protein extraction and SDS-PAGE}

The plant material was ground in a mixture containing $146 \mathrm{mM}$ sucrose, $640 \mathrm{mM}$ 2-mercaptoethanol, $140 \mathrm{mM}$ SDS, $0.25 \mathrm{mM}$ PVP40, and additionally $10 \mathrm{mM}$ PMSF according to $\mathrm{He}$ et al. (2005). The samples were homogenized, pre-centrifuged at $10,000 \times g$ at $4{ }^{\circ} \mathrm{C}$, and centrifuged again for $10 \mathrm{~min}$ at $13,000 \times \mathrm{g}$. The protein concentration was measured according to Bradford (1976) using the BioRad protein assay and BSA as a standard. Samples containing equal amounts of protein $(60 \mu \mathrm{g} /$ well $)$ were subjected to SDS-PAGE as described by Laemmli (1970) at $4{ }^{\circ} \mathrm{C}$ in $6 \%$ stacking and $12 \%$ separating gels.

Protein extraction and native PAGE

LOX activity in electrophoretic gel was carried out according to Heinisch et al. (1996). Deep-frozen plant material was ground in $0.2 \mathrm{M}$ borate buffer at $4{ }^{\circ} \mathrm{C}$. The homogenate was centrifuged at $13,000 \times g$ for $10 \mathrm{~min}$. Samples containing equal amounts of protein $(60 \mu \mathrm{g} / \mathrm{well})$ were subjected to native PAGE at $4{ }^{\circ} \mathrm{C}$ in $5 \%$ stacking and $12 \%$ separating gels. Electrophoretic separation was performed at $4{ }^{\circ} \mathrm{C}$ for $4 \mathrm{~h}$ with a constant voltage $(200 \mathrm{~V})$. The gels were pre-run for $20 \mathrm{~min}$ before the protein samples were loaded. The substrate was prepared by mixing $50 \mu \mathrm{l}$ of linoleic or linolenic acid and $50 \mu \mathrm{l}$ of $96 \%$ ethanol in a $50 \mathrm{ml}$ volumetric flask, which was filled up with $0.2 \mathrm{M}$ borate buffer ( $\mathrm{pH} 7.0$ or 8.0). The staining solution contained $0.5 \mathrm{~g} N, N$-dimethyl-p-phenylenediamine, $4.5 \mathrm{ml}$ methanol, and $0.5 \mathrm{ml}$ acetic acid made up to $50 \mathrm{ml}$ with distilled water.

\section{Western blot analysis}

Proteins resolved by SDS-PAGE were electroblotted to PVDF membranes for $1 \mathrm{~h}$ in a semi-dry transfer unit (Amersham) at $50 \mathrm{~mA}$ of constant current using a transfer buffer ( $25 \mathrm{mM}$ Tris, $192 \mathrm{mM}$ Gly and $20 \% \mathrm{MeOH}, \mathrm{pH}$ 8.3) according to Jungblut (1997). Afterwards, the membranes were blocked overnight in $1 \%(\mathrm{w} / \mathrm{v})$ non-fat dry milk in $10 \mathrm{mM}$ Tris- $\mathrm{HCl}, 0.9 \% \mathrm{NaCl}$, and $\mathrm{pH} 7.4$ at $4{ }^{\circ} \mathrm{C}$ (TBS buffer). After blocking, the blots were incubated with the primary antibody one hour at $4{ }^{\circ} \mathrm{C}$ in TBS buffer diluted to $1: 1,000$. The secondary antibody was goat antirabbit IgG alkaline phosphatase conjugate diluted 1:10,000 in TBS buffer. This antibody was visualized using of BCIP/ NBT-BLUE $^{\circledR}$ from Sigma-Aldrich.

\section{Statistical analysis}

The statistical analysis of intensity of labelling was performed with the Student's $t$ test using SigmaStat 3.5.

\section{Results}

Seed-cone buds of Japanese larch start to develop from dormant buds, which interrupt the dormancy (under the climatic conditions of Central Europe) in March. Dormant seed-cone buds are covered with a thick layer of brown bud scales (Fig. 1a). A single bract dissected from such a seedcone bud is light-coloured, oval in the outline, with a characteristic elongated tip (Fig. 1b). A small seed scale is located at the base of such a bract. Two ovules arranged almost at the right angle to one another are attached to each lateral part of the seed scale.

Although the ovules are only small mounds of meristematic cells, the longitudinal section revealed differentiation of the anatomical structure typical for gymnosperms (Fig. 1c). The wall of the megaspore mother cell is thicker than the other walls of the nucellus cells. Single or grouped 

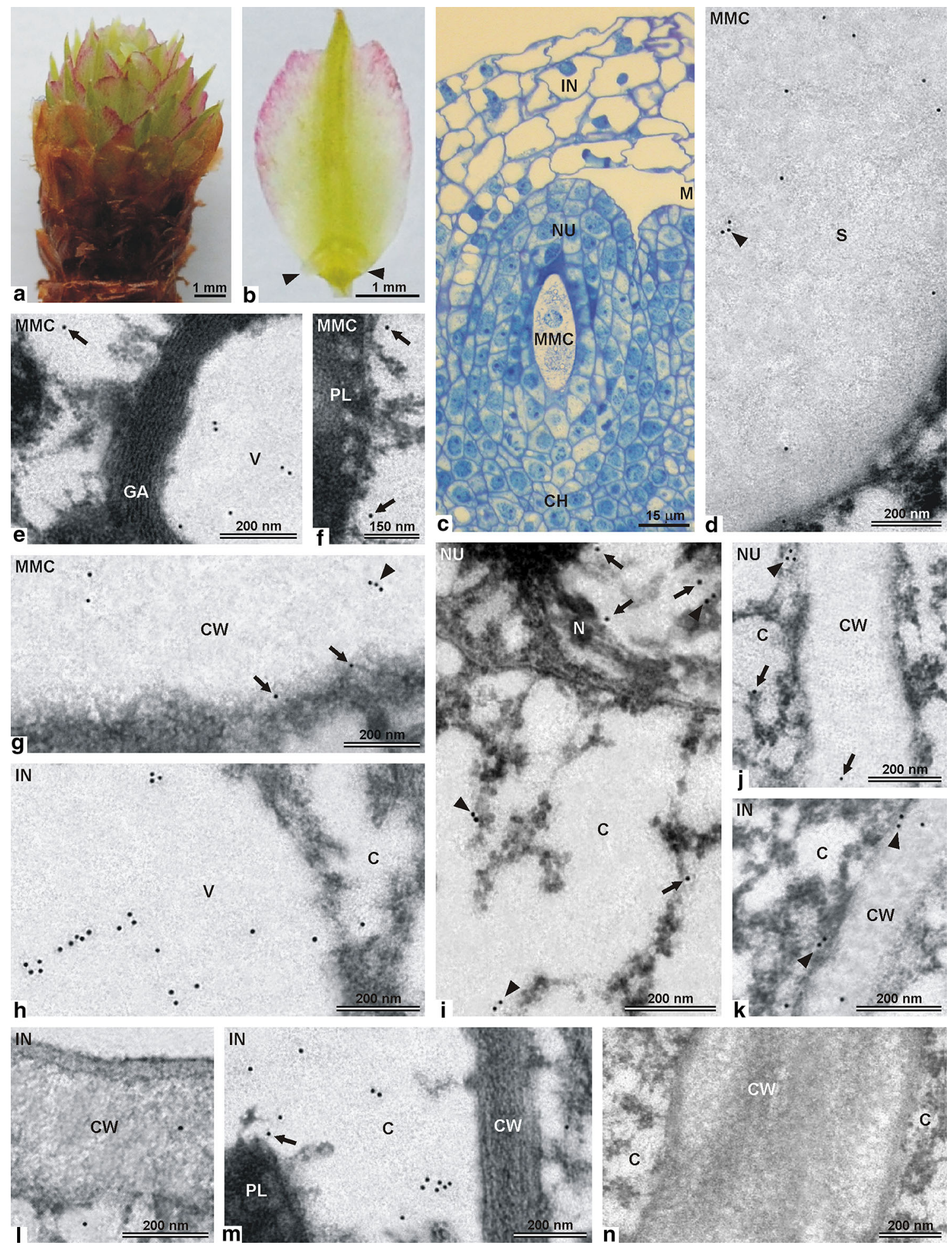

immunogold particles appeared in numerous starch grains inside the megasporocyte, indicating the presence of an enzyme (Fig. 1d). Colloidal gold particles were present in vacuoles and near the Golgi cisterns (Fig. 1e), as well as in the cytoplasm near cell organelles such as plastids
(Fig. 1f). The thick wall of the megaspore mother cell contained single or grouped immunogold particles localized in the central part and at the edge of the cell wall (Fig. 1g). In this structure, presence of two or three gold particles together was frequently observed. 
4Fig. 1 Immunolocalization of lipoxygenase in ovule of L. kaempferi at the stage of the megaspore mother cell in the nucellus. $M M C$ megaspore mother cell, $N U$ nucellus, $I N$ integument, $C W$ cell wall, $C$ cytoplasm, $V$ vacuole. a Intact, young seed-cone of the Japanese larch. b Bract from the cone shown with the seed scale placed at its base (two ovules-arrowheads). c Longitudinal section showing the structure of the ovule with the megasporocyte in the nucellus. $\mathrm{CH}$ chalaza, $M$ micropyle. d Fragment of a starch grain $(S)$ with numerous single or grouped (arrowhead) immunogold particles. e A portion of megaspore mother cell cytoplasm with a Golgi apparatus $(G A)$, and a fragment of a mitochondrion (on the left) and a vacuole. Immunogold particles (arrows) - in the vacuoles and near the Golgi apparatus. f Fragment of the plastid $(P L)$ with single immunogold particles (arrows) in the cytoplasm near the plastid outer membrane. $\mathrm{g}$ Fragment of the megaspore mother cell wall with single or grouped (arrowhead) immunogold particles in the central part and at the edge of the cell wall (arrows). h Fragment of the integument cell with numerous immunogold particles grouped inside the vacuole or single within the vacuole and in the cytoplasm. i Portion of the nucleus $(N)$ and cytoplasm of the nucellus cell with single (arrows) or paired (arrowheads) immunogold particles. j Fragment of the cell wall between two nucellus cells with single (arrows) or grouped (arrowhead) immunogold particles in the area of the cell wall or cytoplasm. k Fragment of the cell wall between two integument cells with single immunogold particles in the area of the cell wall and the dense cytoplasm or paired (arrowheads) immunogold particles at the plasmalemma. I Fragment of the integument cell wall bordering the external environment with a thick (ca. $45 \mathrm{~nm}$ ) cuticle layer. Single immunogold particles are present in the area of the cell wall and in the cytoplasm. m Portions of the cells of the integument outer layer with single or grouped immunogold particles in the cytoplasm and near the plastid $(P L$, arrow). n A control reaction. Fragment of the cell wall between the megaspore mother cell and the nucellus cell

The nucellus and integument cells of the L. kaempferi ovule at the stage of the megaspore mother cell in the nucellus also exhibited immunogold particles. They were scattered in the nucleus near condensed chromatin and the cytoplasm of the nucellus cell (Fig. 1i), and sporadically in the cell walls (Fig. 1j). In the cells of the massive integument, the more numerous immunogold particles were grouped inside the vacuole (Fig. 1h). Single gold particles were observed in the centre of the cell walls and the cytoplasm (Fig. 1k, 1). In the integument cells, single immunogold particles were often found near the plastid (Fig. 1m) and close to the membrane, i.e. the plasmalemma (Fig. 1k). A control reaction was carried out in order to determine the degree of specificity of the immunogold reaction. Only single gold particles (a few per one nickel grid) were found in the specimens-in most grid meshes no gold particles were present like in the cell wall shown in Fig. 1n.

In the Japanese larch ovule, at the stage with megaspore mother cell in the nucellus, the immunogold reaction was most intense in the integument cells. The lowest numbers of colloidal gold particles, indicating the presence of LOX, were found in the megaspore mother cell (Fig. 2a). At this stage, the lipoxygenase activity was the lowest of all the examined stages of ovule development and optimum $\mathrm{pH}$ for the enzyme activity was observed at pH 8.0 (Fig. 2b).
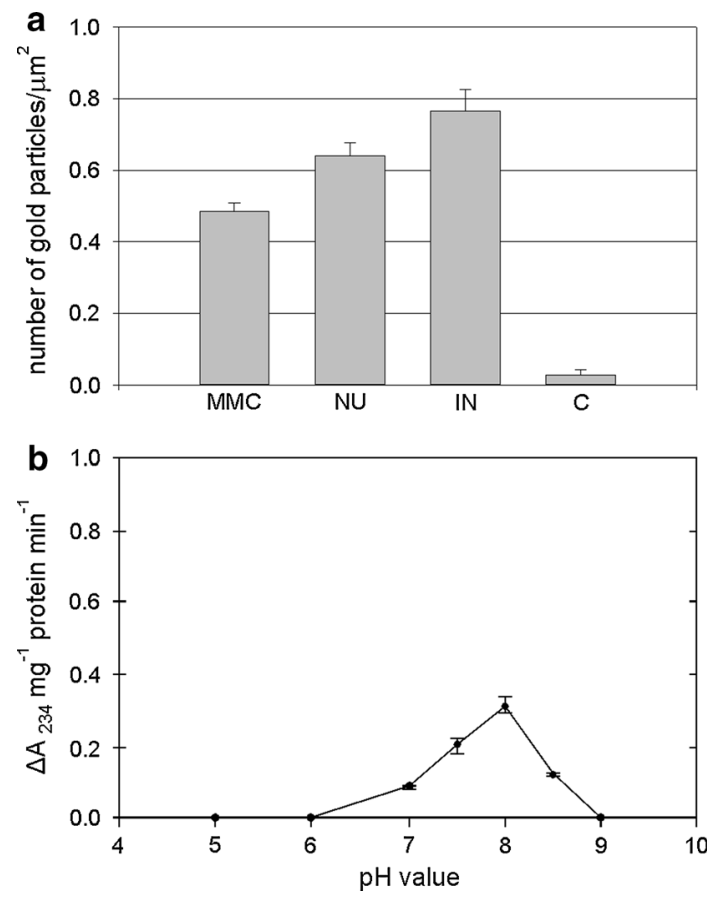

Fig. 2 The amount of the immunogold particles (a) and LOX activity (b) in the L. kaempferi ovule with the megasporocyte in the nucellus. $M M C$ megaspore mother cell, $N U$ nucellus, $I N$ integument, $C$ control

The process of megasporogenesis ends with appearance of haploid megaspores. In all the studied cases, three megaspores arranged in one line were formed after incomplete meiotic division. At the stage with a triad of megaspores in the nucellus, the structure of the ovule did not change drastically in comparison to the stage with the megaspore mother cell in the nucellus (Fig. 3a). Within the linear triad, the micropylar and middle megaspores were relatively smaller (approx. $18 \mu \mathrm{m} \times 15 \mu \mathrm{m}$ and $22 \mu \mathrm{m} \times 15 \mu \mathrm{m}$, respectively) than the largest chalazal megaspore (functional megaspore; $30 \mu \mathrm{m} \times 50 \mu \mathrm{m})$. Apart from the enlarged size, this megaspore differed from the others the presence of a large, centrally located nucleus and numerous starch grains in the cytoplasm. In all the triad megaspores, the frequency of the occurrence of immunogold particles revealing LOX was quite high. Single or aggregated gold particles were found in the vacuoles in the micropylar megaspore (Fig. 3b) and were also present in the cell wall separating the micropylar megaspore from the nucellus cell (Fig. 3c). Similar localization of the immunogold particles was observed in the middle megaspore (Fig. 3d, e). The cytoplasm of both megaspores was condensed and compacted into small, electrondense floccules. In the chalazal megaspore, the immunogold particles were observed in the less homogeneous cytoplasm with clearly visible areas of higher and lower density and in the area of starch grains (Fig. 3g), as well as in the vacuoles and the cell wall (Fig. 3h). 

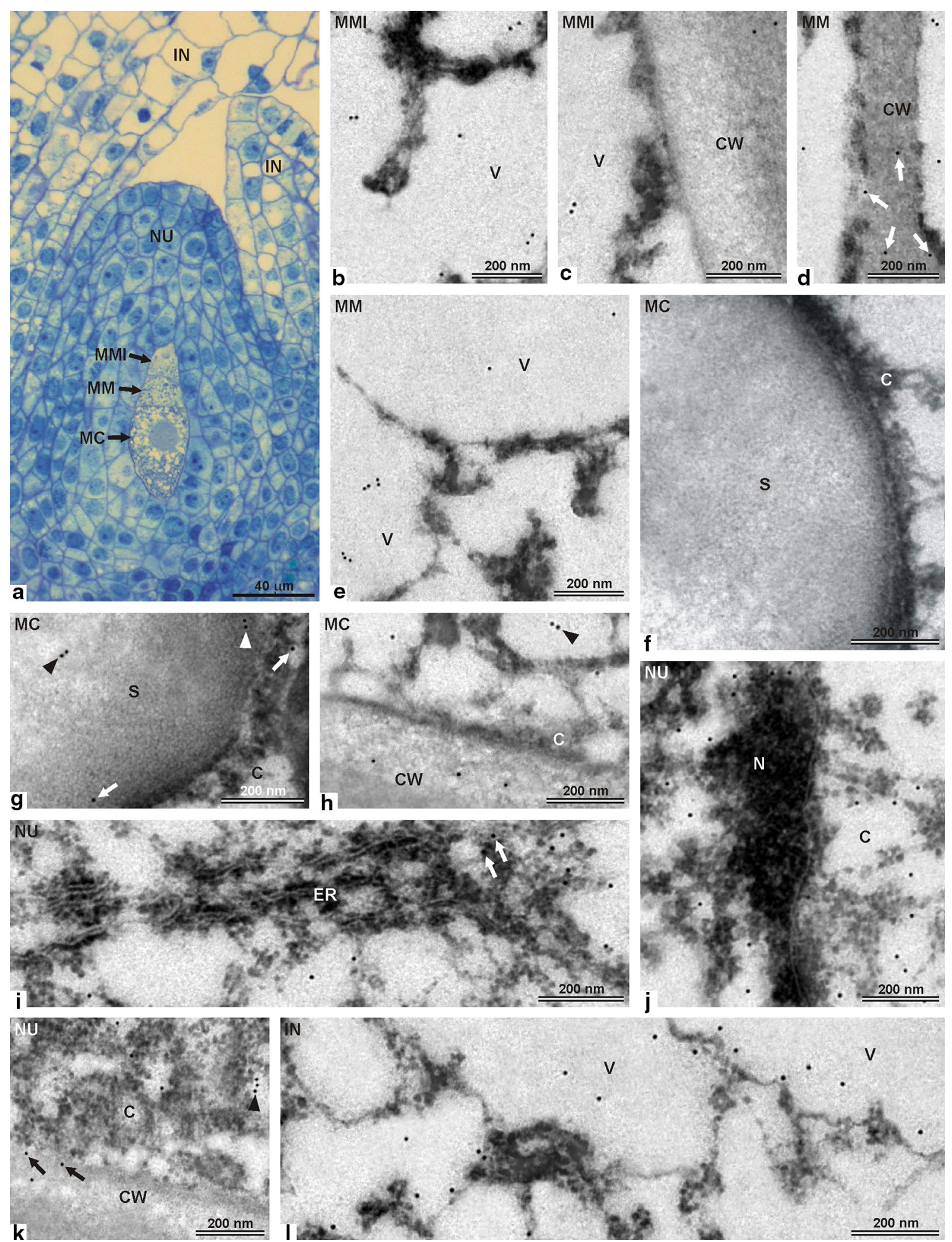

In the nucellus cells, the immunogold particles were most often visible in the cytoplasm, and especially near the endoplasmic reticulum (Fig. 3i). The particles were found also in cell nuclei-in the nucleoplasm and in the area of less condensed chromatin (Fig. 3j), where they were uniformly distributed. The presence of the LOX enzyme was revealed also in the cell walls (Fig. 3k). In comparison to the cytoplasm and vacuoles, where the immunogold particles were single or arranged in groups, the cell wall contained much fewer particles, usually localized at the 
4Fig. 3 Immunolocalization of lipoxygenase in ovule of L. kaempferi at the stage of the triad of megaspores in the nucellus. $M M I$ micropylar megaspore, $M M$ middle megaspore, $M C$ chalazal megaspore, $N U$ nucellus, $I N$ integument, $C W$ cell wall, $C$ cytoplasm, $V$ vacuole. a Longitudinal section of the ovule with the triad of megaspores. b Fragment of a degenerated micropylar megaspore filled with condensed cytoplasm and numerous tiny vacuoles with single or paired immunogold particles. c Fragment of the cell wall separating the micropylar megaspore from the nucellus cell. d Fragment of the cell wall between the micropylar and central megaspores. Immunogold particles visible in the area of the cell wall (arrows) and in the vacuoles. e Single or grouped immunogold particles in the vacuoles of the middle megaspore. $\mathbf{f}$ Control reaction. Portion of the chalazal megaspore with a fragment of a starch grain $(S)$. g Fragment of a starch grain $(S)$ of chalazal megaspore with single (arrows) or paired (arrowheads) immunogold particles. h A part of the cell wall separating the chalazal megaspore from the nucellus cell (paired particles-arrowhead). i Portion of the nucellus cell cytoplasm with immunogold particles at the cistern of the endoplasmic reticulum (ER) (arrows) and its close proximity. j Fragment of the nucellus cell with immunogold particles in the nucleoplasm and in the area of less condensed chromatin. $N$ nucleus. $\mathbf{k}$ Parts of the cytoplasm and the cell wall separating neighbouring nucellus cells. I Fragment of the integument cell with single immunogold particles localized near the tonoplasts and inside the vacuoles

edge. In the integument cells, at the stage of the megaspore triad in the centre, single gold particles were observed in a number of starch granules in the cytoplasm and around the grains, near the nucleus, cell wall, and Golgi cisterns. Single immunogold particles were found at the outer membrane of the nuclear envelope and in the cell walls; the greatest numbers were found in the vacuoles, both in their central parts and near the tonoplasts (Fig. 31). No immunogold particles were found in the control reaction (Fig. 3f).

In the triad of megaspores, the largest number of immunogold particles was found in the chalazal megaspore and the lowest - in the micropylar megaspore. Very intense immunogold reaction was also observed in the cells of the integument. The lowest number of immunogold particles indicating the presence of the LOX enzyme was in the nucellus (Fig. 4a). In the larch ovules with the triad of megaspores in the nucellus, LOX activity was higher than that measured at the previous stage of ovules development. At this stage, the second LOX activity at $\mathrm{pH} 7.0$ was found (Fig. 4b).

Immunodetection using anti-LOX clearly demonstrated occurrence of lipoxygenase in the buds of L. kaempferi (Fig. 5a). The enzyme activity with optima at $\mathrm{pH} 7.0$ and 8.0 (Fig. 4b) was confirmed using the method of staining of dioxygenation products in electrophoretic gel with linoleic and linolenic acid as a substrate (Fig. 5b-e). More intense reaction was detected at $\mathrm{pH} 8.0$ with linoleic (Fig. 5c) and linolenic acid (Fig. 5e) as a substrate, in comparison with LOX activity at pH 7.0 (Fig. 5b, d).
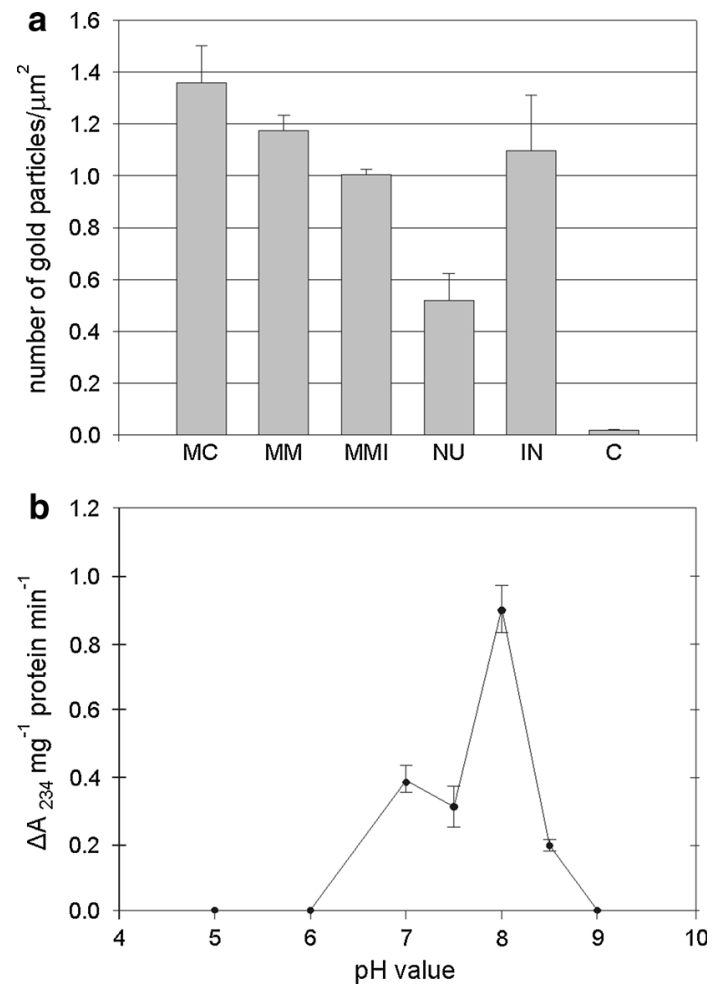

Fig. 4 The amount of the immunogold particles (a) and LOX activity (b) in the L. kaempferi ovule with the triad of megaspores in the nucellus. $M C$ chalazal megaspore, $M M$ middle megaspore, $M M I$ micropylar megaspore, $N U$ nucellus, $I N$ integument, $C$ control

\section{Discussion}

Like others members of the Larix genus, the Japanese larch has an annual cycle of sexual reproduction. During four growing seasons (2006-2008 and 2013), the divisions of megaspore mother cells were observed in early April, and the development of a functional megaspore and degradation of other cells of the triad-in mid-April. Megasporogenesis in L. kaempferi growing in the climatic conditions of eastern Poland occurs in the first half of April. The first steps of development of the L. kaempferi ovule are similar to those in L. decidua (Slobodník and Guttenberger 2000). The tetrad of megaspores was not noticed in any studied cases, which is consistent with the observation of L. occidentalis (Owens and Molder 1979) and L. decidua (Kosiński 1986; Slobodník and Guttenberger 2000).

In developing L. kaempferi ovules, the presence of LOX with two optima for its activity-at $\mathrm{pH} 8.0$ and $\mathrm{pH} 7.0$ was found. The enzyme with the activity at $\mathrm{pH} 8.0$ occurred at both the investigated stages; the other one (at $\mathrm{pH} 7.0$ ) was detected only at the stage with the triad of megaspores in the nucellus. The increase in the quantity of the immunogold particles in the ovule with the triad of megaspores was accompanied by enhanced LOX activity at $\mathrm{pH}$ 8.0, 


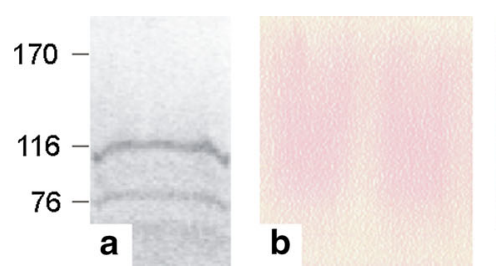

Fig. 5 Identification of lipoxygenase in the ovule of L. kaempferi. Western blot analysis (a) clearly demonstrated occurrence of lipoxygenase in the buds of L. kaempferi. The electrophoretic pattern

compared to the previous stage of ovule development. At this stage, another optimum for the enzyme activity at $\mathrm{pH}$ 7.0 was found, suggesting the presence of another isoform of lipoxygenase. It was found that LOX activity in developing ovules of the Japanese larch was not correlated with the number of antibody-labelled molecules located in the ovules during megasporogenesis. At the stage with the megasporocyte in the nucellus, the cells of Japanese larch ovules contained a relatively large number of particles, and, paradoxically, low catalytic activity of LOX. It seems that a large part of the enzyme molecules occurred in an inactive form at this stage, performing the functions of storage proteins. Occurrence of vegetative lipoxygenases (VLXs) was confirmed in soybeans. In soybean seedlings, VLXs function as temporary nitrogen stores in the cell layer located around the pith of the vascular bundles before redistribution thereof to other tissues. Storage LOXs and VLXs, called C and D, exhibit enzymatic activity in soybean seeds (Fischer et al. 1999). A bigger number of immunogold particles indicating the presence of LOX were found in the ovule at the stage with the triad of megaspores in the nucellus. At this stage, the second peak (at $\mathrm{pH}$ 7.0) of LOX activity occurs, suggesting appearance of another catalytically active LOX isoform. Lipoxygenase isoforms, which differ in biochemical and kinetic properties, can perform different functions in plants. In addition, some isoforms of LOX are synthesized only at certain stages of development (Royo et al. 1996, Hughes et al. 1998, Fuller et al. 2001). Our study indicated the occurrence of a LOX isoform characteristic only to ovules with the triad of megaspores in nucellus. At the later stages of ovule development, the presence of lipoxygenase with the activity at $\mathrm{pH} 7.0$ was not detected [unpublished data].

LOX is suggested to play a role in membrane degradation by induction of the collapse of the tonoplast and nuclear and plasma membrane during programmed cell death (PCD) in tapetal cells of Gagea lutea (Szczuka et al. 2006) and Lathyrus undulatus (Vardar and Ünal 2011). The increase in the amount of immunogold particles and LOX activity at the stage with the triad of megaspores in the nucellus suggests that the inactive enzyme of the earlier stage is activated and/or a new active enzyme is produced. LOX present in the chalazal megaspore may play a role in of LOX activity in the extract from the ovule of L. kaempferi using as a substrate: b linoleic acid at $\mathrm{pH} 7.0$, c linoleic acid at $\mathrm{pH} 8.0$, d linolenic acid at $\mathrm{pH} 7.0$, e linolenic acid at $\mathrm{pH} 8.0$

lipid mobilization and/or nitrogen storage; enzymes from the middle and micropylar megaspores are probably involved in membrane degradation connected with degeneration of nonfunctional megaspores.

Lipoxygenase was localized in chloroplasts (in the internal membrane of the plastid envelope and in stroma), vacuoles, cytoplasm, mitochondria, and plasmalemma of various plant cells (Bowsher et al. 1992; Feussner et al. 1995; Blée and Joyard 1996; Fischer et al. 1999; Braidot et al. 2004). In developing ovules of L. kaempferi, LOX was also found in the membranes of Golgi apparatus and endoplasmic reticulum, in cell walls, amyloplasts, and nuclei of all the investigated cells. The location of LOX molecules was rather random; groups of immunogold particles were often observed in the vacuoles of integument cells. The integument, the most external part of the ovules, is exposed to various environmental factors. At both stages, the amount of the enzyme was quite high in the integument, suggesting involvement of LOX in the mechanisms of response to/defence against environmental factors.

Acknowledgments Polyclonal antibody against LOX was produced by Agrisera, SE-911 21 Vännäs, Sweden (www.agrisera.se).

Open Access This article is distributed under the terms of the Creative Commons Attribution License which permits any use, distribution, and reproduction in any medium, provided the original author(s) and the source are credited.

\section{References}

Avanci NC, Luche GH, Goldman GH, Goldman MHS (2010) Jasmonates are phytohormones with multiple function, including plant defense and reproduction. Genet Mol Res 9:484-505

Beneytout J, Andrianarison R, Rakotoarisoa Z, Tixier M (1989) Properties of a lipoxygenase in green algae (Oscillatoria sp.). Plant Physiol 91:367-372

Blée E, Joyard J (1996) Envelope membranes from spinach chloroplasts are a site of metabolism of fatty acid hydroperoxides. Plant Physiol 110:445-454

Bowsher CG, Ferrie BJ, Ghosh S, Todd J, Thompson JE, Rothstein SJ (1992) Purification and partial characterization of a membraneassociated lipoxygenase in tomato fruit. Plant Physiol 100:1802-1807

Bradford M (1976) A rapid and sensitive method for the quantitation of microgram quantities of protein utilizing the principle of protein-dye binding. Anal Biochem 72:248-254 
Braidot E, Petrussa E, Micolini S, Tubaro F, Vianello A, Macri F (2004) Biochemical and immunochemical evidences for the presence of lipoxygenase in plant mitochondria. J Exp Bot 55:1655-1662

Brash AR (1999) Lipoxygenases occurrence, function, catalysis, and acquisition of substrate. J Biol Chem 274:23679-23682

Dubbs WE, Grimes HD (2000) The mid-pericarp cell layer in soybean pod walls is a multicellular compartment enriched in specific lipoxygenase isoforms. Plant Physiol 123:1281-1288

Feussner I, Kindl H (1994) Particulate and soluble lipoxygenase isoenzymes. Planta 194:22-28

Feussner I, Wasternack C (2002) The lipoxygenase pathway. Annu Rev Plant Biol 53:275-297

Feussner I, Hause B, Vörös K, Parthier B, Wasternack C (1995) Jasmonate-induced lipoxygenase forms are localized in chloroplasts of barley leaves (Hordeum vulgare cv. Salome). Plant J 7:949-957

Feussner I, Kühn H, Wasternack C (2001) Lipoxygenase-dependent degradation of storage lipids. Trends Plant Sci 6:268-273

Fischer AM, Dubbs WE, Baker RA, Fuller MA, Stephenson LC, Grimes HD (1999) Protein dynamics, activity and cellular localization of soybean lipoxygenases indicate distinct functional roles for individual isoforms. Plant J 19:543-554

Fukuchi-Mizutani M, Ishiguro K, Nakayama T, Utsunomiya $\mathrm{Y}$, Tanaka Y, Kusymi T, Ueda T (2000) Molecular and functional characterization of a rose lipoxygenase cDNA related to flower senescence. Plant Sci 160:129-137

Fuller MA, Weichert H, Fischer AM, Feussner I, Grimes HD (2001) Activity of soybean lipoxygenase isoforms against esterified fatty acid indicates functional specificity. Arch Biochem Biophys 388:146-154

Gfeller A, Dubugnon L, Liecht R, Farmer EE (2010) Jasmonate biochemical pathway. Sci Signal 3(109):cm3. doi:10.1126/ scisignal. $3109 \mathrm{~cm} 3$

Gomi K, Yamamoto H, Akimistu K (2002) Characterization of a lipoxygenase gene in rough lemon induced by Alternaria alternata. J Gen Plant Pathol 68:21-30

Grayburn WS, Schneider GR, Hamilton-Kemp TR, Bookjans G, Ali K, Hildebrand DF (1991) Soybean leaves contain multiple lipoxygenases. Plant Physiol 95:1214-1218

Hall JP, Brown IR (1977) Embryo development and yield of seed in Larix. Silvae Genet 26:77-84

Hamberg M (1986) Isolation and structure of lipoxygenase from Saprolegnia parasitica. Biochim Biophys Acta 876:688-692

He CY, Zhang JG, Duan AG, Yin JY, Zhou DS (2005) Comparison of methods for protein extraction from pine needles. For Sci Pract 7:20-23

Heinisch O, Kowalski E, Tauscher B, Ludwig H (1996) Staining for soybean lipoxygenase activity in electrophoretic gels. Fett/Lipids 5:183-184

Hughes RK, Wu Z, Robinson DS, Hardy D, West SI, Fairhurst SA, Casey R (1998) Characterization of authentic recombinant peaseed lipoxygenases with distinct properties and reaction mechanisms. Biochem J 333:33-43

Jungblut P (1997) Semi-Dry Blotting onto Hydrophobic Membranes. In: Kamp RM, Choli-Papadopoulou T, Wittmann-Liebold B (eds) Protein structure analysis. Springer, Berlin, pp 215-227

Kim ES, Choi E, Kim Y, Cho K, Lee A, Shim J, Rakwal R, Agrawal GK, Han O (2003) Dual positional specificity and expression of non-traditional lipoxygenase induced by wounding and methyl jasmonate in maize seedlings. Plant Mol Biol 52:1203-1213

Koda Y (1997) Possible involvement of jasmonates in various morphogenic events. Physiol Plant 100:639-646

Kolomiets MV, Hannapel DJ, Chen H, Tymeson M, Gladon RJ (2001) Lipoxygenase is involved in the control of potato tuber development. Plant Cell 13:613-626
Kosiński G (1986) Megagametogenesis, fertilization, and embryo development in Larix decidua. Can J For Res 16:1301-1309

Kosiński G (1987) Empty seed production in European larch (Larix decidua). For Ecol Manag 19:241-246

Laemmli UK (1970) Cleavage of structural proteins during the assembly of the head of bacteriophage T4. Nature 227:680-685

Li L, Li C, Howe GA (2001) Genetic analysis of wound signaling in tomato. Evidence for a dual role of jasmonic acid in defense and female fertility. Plant Physiol 127:1414-1417

Melan MA, Dong X, Endars ME, Davis KR, Ausubel FM, Peterman TK (1993) An Arabidopsis thaliana lipoxygenase gene can be induced by pathogens, abscisic acid, and methyl jasmonate. Plant Physiol 101:441-450

Nakashima A, Iijima Y, Aoki K, Shibata D, Sugimoto K, Takabayashi J, Matsui K (2011) Monogalactosyl diacylglycerol is a substrate for lipoxygenase: its implications for oxylipin formation directly from lipids. J Plant Interact 6:93-97

Nam KH, Yoshihara T (2012) Interactions among LOX metabolites regulate temperature-mediated flower bud formation in morning glory (Pharbitis nil). J Plant Physiol 169:1815-1820

Owens JN, Molder M (1979) Sexual reproduction of Larix occidentalis. Can J Bot 57:2673-2690

Owens JN, Morris SJ, Catalano GL (1994) How the pollination mechanism and prezygotic and postzygotic events affect seed production in Larix occidentalis. Can J For Res 24:917-927

Philipson JJ (1996) Effects of girdling and gibberellin A4/7 on flowering of European and Japanese larch grafts in an outdoor clone bank. Can J For Res 26:355-359

Porta H, Rocha-Sosa M (2002) Plant lipoxygenases. Physiological and molecular features. Plant Physiol 130:15-21

Royo J, Vancanneyt G, Pérez AG, Sanz C, Störmann K, Rosahal S, Sánchez-Serrana JJ (1996) Characterization of three potato lipoxygenases with distinct enzymatic activities and different organ-specific and wound-regulated expression patterns. J Biol Chem 271:21012-21019

Schechter G, Grossman S (1983) Lipoxygenase from baker's yeast: purification and properties. Int J Biochem 15:1295-1304

Schewe T, Rapoport SM, Kühn H (1986) Enzymology and physiology of reticulocytes lipoxygenase: comparison with other lipoxygenases. Adv Enzymol Relat Areas Mol Biol 58:191-272

Schmitt NF, van Mechelen JR (1997) Expression of lipoxygenase isoenzymes in developing barley grains. Plant Sci 128:141-150

Shibata D, Steczko J, Dixon JE, Hermodson M, Yazdanparast R, Axelrod B (1987) Primary structure of soybean lipoxygenase-1. J Biol Chem 262:10080-10085

Siedow J (1991) Plant lipoxygenase: structure and function. Annu Rev Plant Physiol Plant Mol Biol 42:145-188

Skórzyńska-Polit E, Krupa Z (2003) Activity of lipoxygenase in Arabidopsis thaliana - a preliminary study. Cell Molec Biol Lett 8:279-284

Skórzyńska-Polit E, Pawlikowska-Pawlęga B, Szczuka E, Drążkiewicz M, Krupa Z (2006) The activity and localization of lipoxygenases in Arabidopsis thaliana under cadmium and copper stresses. Plant Growth Reg 48:29-39

Slobodník B (2002) Pollination success and full seed percentage in European larch (Larix decidua MILL.). J For Sci 48:271-280

Slobodník B, Guttenberger H (2000) Ovule, megaspores, and female gametophyte formation in Larix decidua Mill. (Pinaceae). Acta Biol Cracov Bot 42:93-100

Slobodník B, Guttenberger H (2005) Zygotic embryogenesis and empty seed formation in European larch (Larix decidua Mill.). Ann For Sci 62:129-134

Smith J, Linforth R, Tucker GA (1997) Soluble lipoxygenase isoforms from tomato fruit. Phytochemistry 45:453-458 
Sofo A, Dichio B, Xiloyannis C, Masia A (2004) Lipoxygenase activity and proline accumulation in leaves and roots of olive trees in response to drought stress. Physiol Plant 121:58-65

Stephenson LC, Bunker TW, Dubbs WE, Grimes HD (1998) Specific soybean lipoxygenases localize to discrete subcellular compartments and their mRNAs are differentially regulated by source-sink status. Plant Physiol 116:923-933

Stumpe M, Bode J, Göbel C, Wichard T, Schaaf A, Frank W, Frank M, Reski R, Pohnert G, Feussner I (2006) Biosynthesis of C9aldehydes in the moss Physcomitrella patens. Biochim Biophys Acta 1761:301-312
Suurmeijer C, Pérez-Gilabert M, van der Hijden H, Veldink GA, Vliegenthart J (1998) Purification, product characterization and kinetic properties of soluble tomato lipoxygenase. Plant Physiol Biochem 36:657-663

Szczuka E, Skórzyńska-Polit E, Pawlikowska-Pawlęga B, Sobieska J, Gawron A (2006) Localization of lipoxygenase in the anther of Gagea lutea (L.) Ker.-Gaw. Acta Biol Cracov Bot 48:19-26

Vardar F, Ünal M (2011) Immunolocalization of lipoxygenase in the anther wall cells of Lathyrus undulatus Boiss. during programmed cell death. Not Bot Hort Agrobot Cluj 39:71-78

Zimmerman DC, Vick BA (1973) Lipoxygenase in Chlorella pyrenoidosa. Lipids 8:264-266 